\title{
Effect of Plant Maturity on the Proximate Composition of Sesamum Radiatum Schum Leaves
}

\author{
Oduntan A. O. \& Olaleye O. \\ National Horticultural Research Institute, P. M. B. 5432, Idi-Ishin, Ibadan \\ E-mail: bosetunde12@yahoo.com
}

\begin{abstract}
Akinwande B. A.
Department of Food Technology, Ladoke Akintola University of Technology, Ogbomoso
\end{abstract}

Received: May 15, 2012

doi:10.5296/jfs.v1i1.1806
Accepted: October 2, 2012 Published: December 1, 2012

URL: http://dx.doi.org/10.5296/jfs.v1i1.1806

\begin{abstract}
This study investigated the effect of maturity on the nutrients of Sesamum radiatum leaves. Sesamum radiatum seeds were sown on an unfertilized land and the leaves were harvested on weekly basis from the fourth to the tenth week after planting (WAP) when senenescence has started setting in. The moisture, protein, fat, crude fibre, ash, and nitrogen free extract of the plant were determined using A.O.A.C standard methods. The results obtained showed high moisture content which decreased from the fourth week after planting (4WAP) till the 10WAP (91.73\% - 48.19\%), the minimum value for ash $(13.50 \%)$ was observed at 6 WAP while the maximum value $16.57 \%$ was observed at the $10 \mathrm{WAP}$. The crude protein content increased from 4 WAP (23.86\%) till 7 WAP (24.69\%) and reduced till final harvesting at 10 WAP (23.29\%), fat content ranges from 5.48\% - 8.27\%, fiber content increased from the 4 WAP till 10 WAP, nitrogen free extract revealed fluctuating values (46.05\% - 50.53\%). The study indicated that as the leaf matures the nutritional quality increases and the optimum value for crude protein was observed at 7 WAP.
\end{abstract}

Keywords: Sesamum radiatum, Plant maturity, Proximate composition, Leaves 


\section{Introduction}

Sesamum radiatum is a leafy vegetable called "ekuku gogoro" in Yoruba language belonging to the group of indigenous vegetable that grow in small quantity in the rural areas. The plant occurs throughout the tropical Africa mainly as weed, where it is gathered in the wild and used as a potherb (Auwalu and Babatunde, 2007). It is one of the many neglected leafy vegetables of the tropics despite its nutritional contribution. It is sometimes cultivated to be used as an ingredient that increases the desirable viscosity of sauces. These sauces are mixed with mashed food prepared from cereals or root crop flours, where it adds to the protein, vitamin and mineral contents of predominantly starchy diets of the people of the areas concerned (Oyenuga and Fetuga, 1975; Omidiji, 1978).

Vegetables are generally succulent parts of plants grown in gardens and consumed as a side dish with starchy staples (Guarino, 1995). Several vegetable species abound in the world. Green leafy vegetables constitute an indispensable constituent of human diet in Africa generally and West Africa in particular. (Chima and Igyor, 2007).

Leafy vegetables are important items of diet in many Nigerian homes and they are valuable sources of nutrients especially in rural areas where they contribute substantially to protein, mineral, vitamins, fiber and other nutrients which are usually in short supply in daily diets. (Mosha and Gaga, 1999). Optimum utilization of indigenous vegetable will also have significant influence on the income of farmers and traders, especially women, and thereby results on the economic growth of the communities and the nation as a whole. Efforts to encourage the utilization of crops like Sesamum radiatum vegetable require information on its proximate composition and the relationship between its stages of maturity.

The present study was thereby aimed at examining the best harvesting time for the leaves of Sesamum radiatum for optimal benefit to the consumer.

\section{Materials and Methods}

\section{Land Preparation and Planting}

The study was carried out at the experimental research field of the National Horticultural Research Institute (NIHORT), Ibadan, Nigeria. Ibadan is located on Latitude $7^{0} 30^{\prime} \mathrm{N}$ and longitude $3^{0} 54^{\prime} \mathrm{E}, 168 \mathrm{~m}$ above sea level (a.s.l.). Annual temperature ranges from an average minimum of $21^{\circ} \mathrm{C}$ to a mean maximum of $32^{\circ} \mathrm{C}$ while mean monthly relative humidity ranges between 61\% to 83\%. The experiment was conducted between July and October 2010.

Land was cleared, ploughed, harrowed and thereafter beds measuring 2 by $2 \mathrm{~m}$ were made with alleys of $1 \mathrm{~m}$ in between each bed. The experiment was established using a randomized complete block design (RCBD) with three replicates and each replicate was sub-divided into 10 sub plots. The seeds were sown $30 \mathrm{~cm}$ inter and intra spacing. Normal agronomic practices were observed on the field.

Sesamum radiatum seeds were obtained from a farmer in Oke-Ogun area of Oyo State. The seeds were cleaned, sorted to remove damaged seeds and sown on an unfertilized land. Three seeds were sown per hole. 


\section{Selection, Sampling, Harvesting and Sample Preparation}

In the experiment, dates of shoot emergence from the seeds were noted and only shoots that emerged within the first week after the first emergence were tagged. This was done to ensure some measure of uniformity in age of sampled plants. Plants were randomly sampled at weekly interval from the fourth week after sowing till the leaves become very narrow and unappealing. Final harvesting was done at tenth week after sowing, when the leaves were narrow and the stem woody. The whole plants were harvested by uprooting only from tagged plants and used for subsequent samplings and evaluation.

The whole plants were washed with water, drained and dried at a temperature of $50{ }^{0} \mathrm{C}$ for 16 to 24 hrs. The leaves of the dried samples were plucked, milled to flour using blender, packaged in polyethylene bag and sealed for further analyses.

The proximate composition was determined by the method of AOAC (2000). The results were expressed as mean of three assays.

\section{Statistical Analysis}

The data were subjected to Statistical analysis using SAS Package. Analysis of variance (ANOVA) was used to determine the means. Fisher test was used in determining the least significant difference (LSD) of the mean. Test of significant was done at 5\% probability level.

\section{Results and Discussion}

\subsection{Moisture content of fresh leaves}

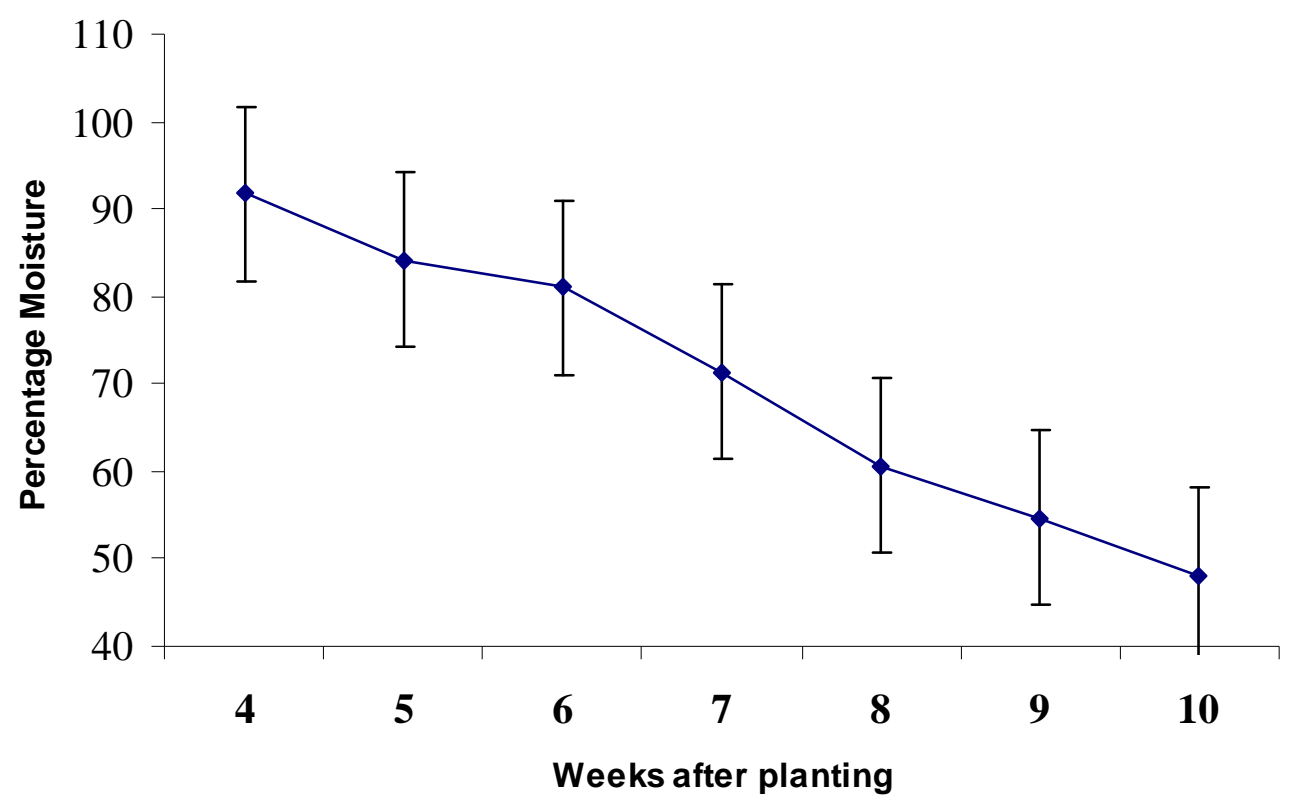

Figure 1. Moisture content of fresh leaves with increase in age of plant 


\section{Macrothink

Figure 1 shows that the fresh leaves of Sesamum radiatum have high moisture content which decreased from 4 WAP (91.73\%) to 10WAP (48.19\%). Stage of maturity had significant ( $\mathrm{p}<$ 0.05 ) effect on the moisture content of the plant. Moisture content is a widely used parameter in the processing and testing of food. It is an index of water activity of many foods. The observed value implies that the leaf may have a short shelf life since microorganisms that cause spoilage thrive in foods having high moisture content and also indicate low total solids (Adepoju et al., 2006). The possibility of spoilage however reduces with maturity of the leaves as indicated by the decrease in moisture content.

\subsection{Proximate Composition of dry leaves}

\subsubsection{Ash content}

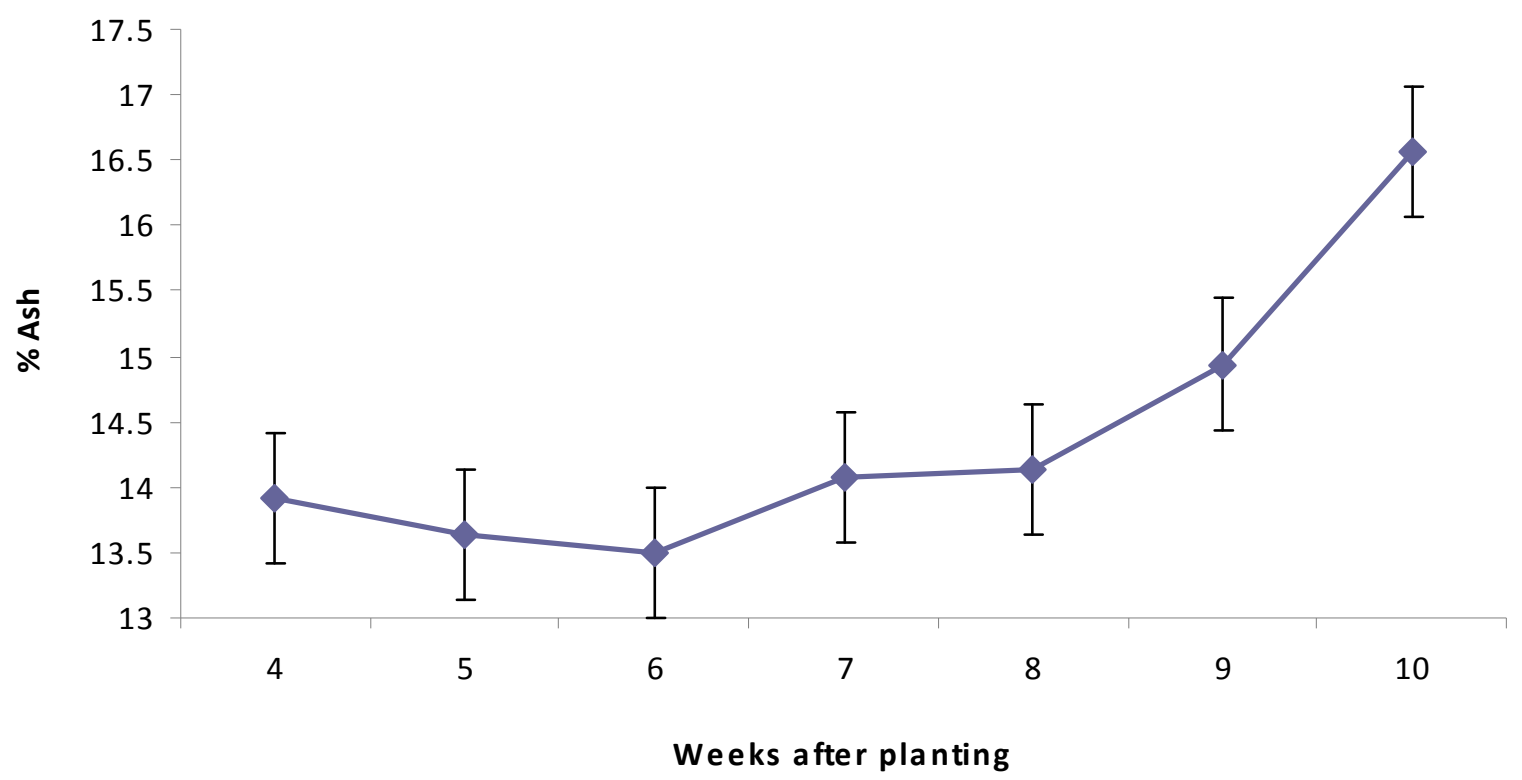

Figure 2a. Ash content of leaves with increase in age of plant

Figure 2a shows the ash content of the leaves with maturity. It decreased from 4 WAP (13.92\%) to 6 WAP (13.64\%) subsequently increased till 10 WAP (16.57\%) when maximum value was obtained. There was significant difference in the ash content between 4WAP and 10 WAP. Ash content, which is an index of mineral contents in biota, is relatively high in Sesamum radiatum leaf when compared to the values reported in leaves of Hibiscus esculentus (8.00\% DW) by Akindahunsi and Salawu, (2005). The ash content, however, is within the range of values $(16.30 \%-17.31 \%)$ reported for some vegetables by Dairo and Adanlawo (2007).

\subsubsection{Protein content}

The crude protein content increased from 4 WAP (23.86\%) till 7 WAP (24.69\%) and reduced till final harvesting was done at 10 WAP when least value of $23.29 \%$ was obtained Figure $2 \mathrm{~b}$ ). 


\section{Macrothink}

Journal of Food Studies

ISSN 2166-1073

2012, Vol. 1, No. 1

The protein value observed in this study was between $23.29 \%$ and $24.69 \%$, which is higher than 3.3\% recorded by the USDA Nutrient Database for Standard Reference (Hall, 1998). This makes the plant advantageous as a rich source of vegetable protein over some vegetables such as raw cocoyam leaf (3.4\%), cooked cocoyam leaf (2.1\%), Amaranthus (6.1\%) and Moringa oleifera (4.2\%) as reported by Adepoju et al. (2006). There was no significant difference in the values of the protein content with the maturity of the plant

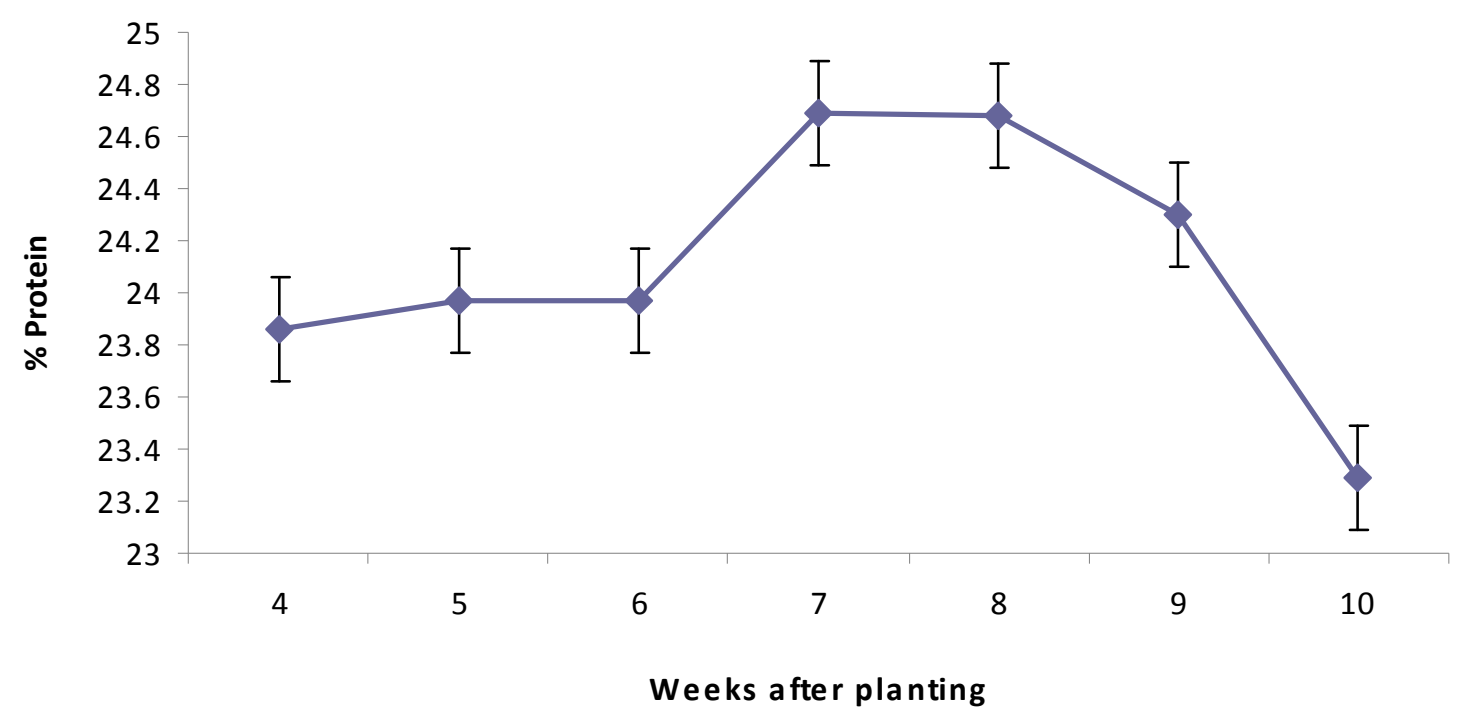

Figure 2b. Protein content of leaves with increase in age of plant

\subsubsection{Fat content}

The fat content of Sesamum radiatum does not follow any definite trend which means that the stage of maturity does not affect it. It ranged from $5.48 \%$ to $8.27 \%$ as shown in Figure 2c. The values revealed that the plant is lower in fat content compared with some Nigerian vegetables like Crassocephalum crepidiodes (12.45\%) and Senecio biafrae (14.21\%) (Dairo and Adanlawo, 2007), but higher than value reported for Brassica oleraceae $(0.26 \%)$ (Emebu and Anyika, 2011). 


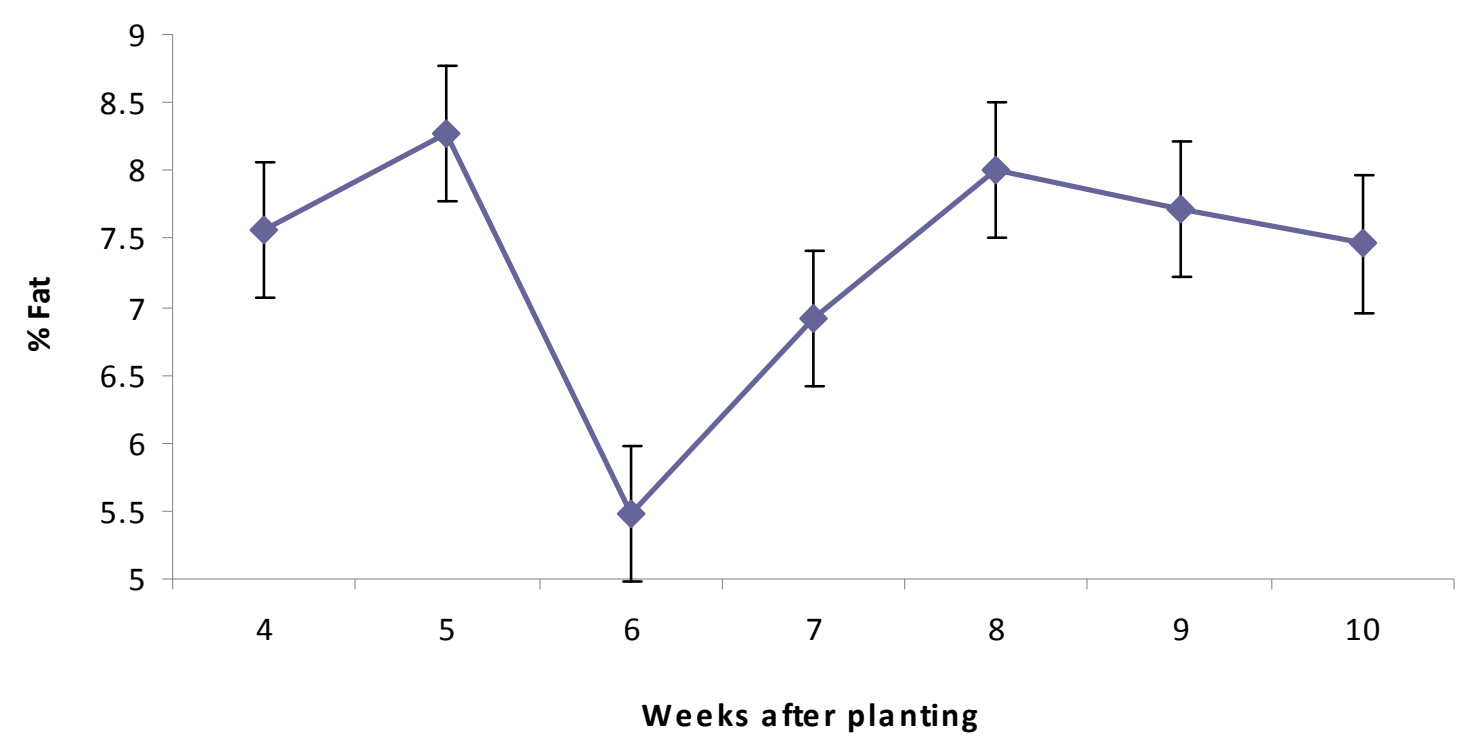

Figure 2c. Fat content of leaves with increase in age of plant

\subsubsection{Fiber content}

The Fiber content of the leaves was lowest at 4 WAP (1.00\%) and increased till the 10 WAP (1.84\%) as shown in Figure 2d. This shows that as the plant matures, it becomes more fibrous hence the increase in the fiber content. There was significant difference in the fibre content at the fourth and other weeks after planting while no significant difference was observed from 5 WAP through to the 10 WAP.

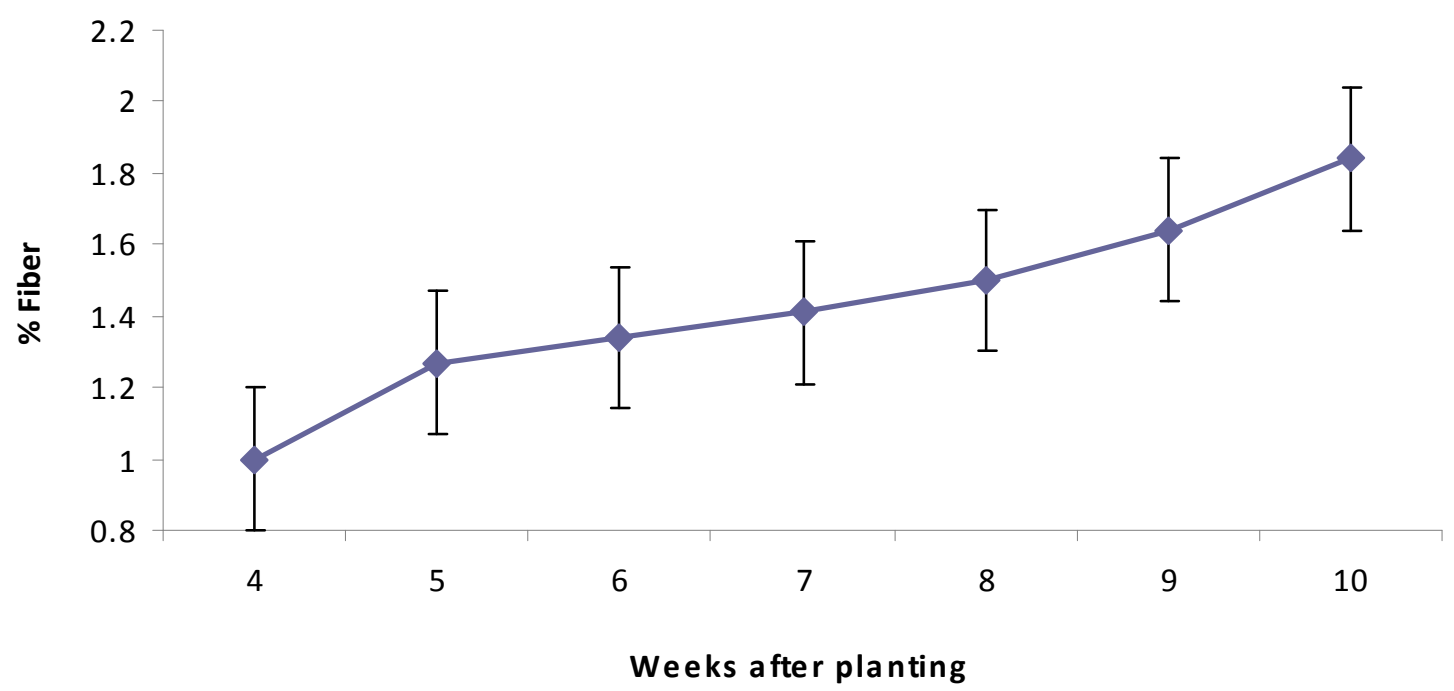

Figure 2d. Fibre content of leaves with increase in age of plant 


\section{Macrothink}

However, the fibre content is lower than that of some Nigerian vegetables like Crassocephalum crepidioides and Senecio biafrae as reported by Dairo and Adanlawo (2007), as well as Amaranthus hybridus (8.61\%) reported by Akubugwo et al., (2007). Fiber in food cleanses the digestive tract by removing potential carcinogens from the body and prevents the absorption of excess cholesterol. Fiber also adds bulk to the food and prevents the intake of excess starchy foods and may therefore guard against metabolic conditions such as hypercholesterolemia and diabetes mellitus. (Mensah et al., 2008)

\subsubsection{Nitrogen Free Extract}

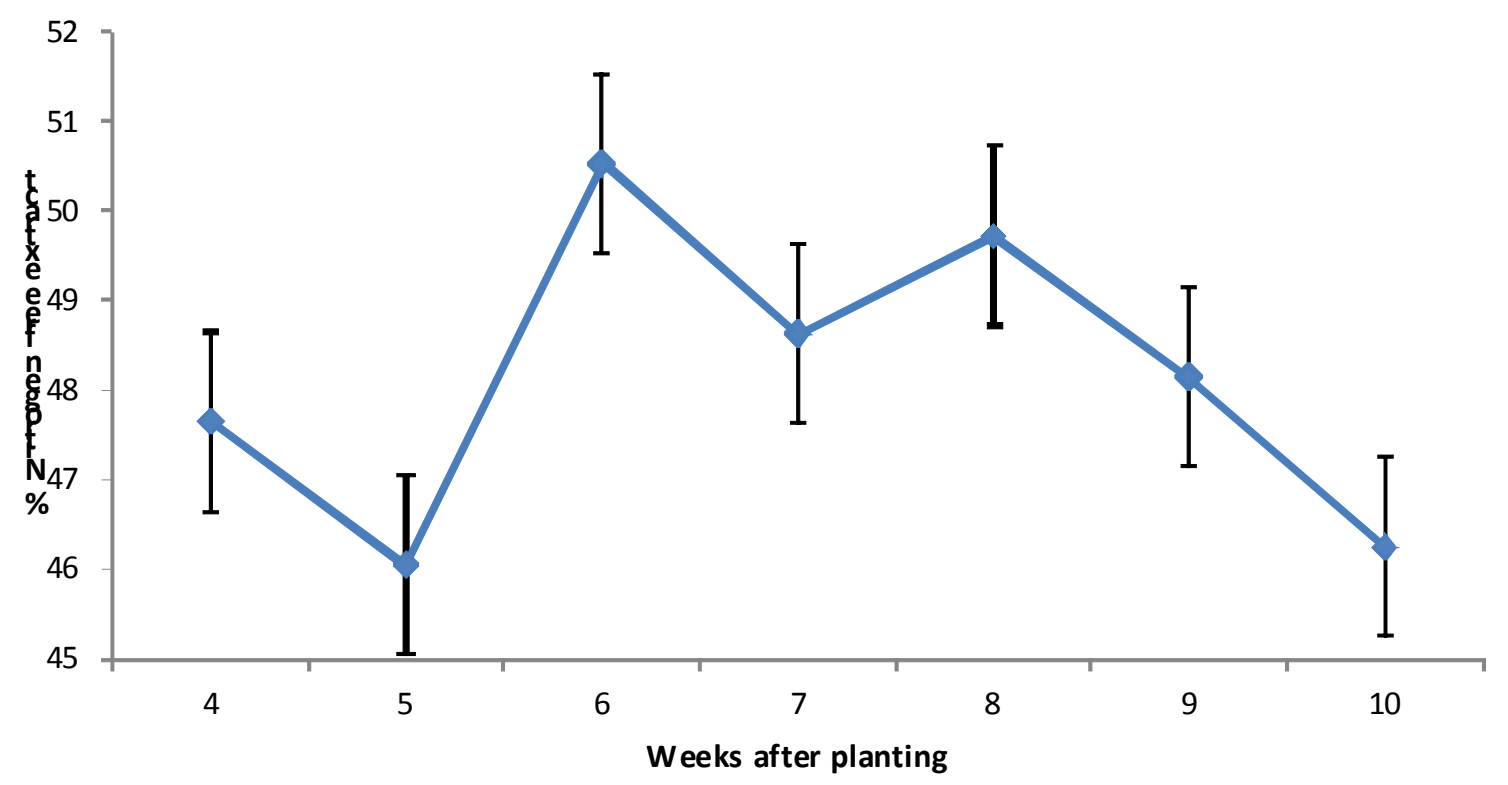

Figure 2e. Nitrogen free extract content of leaves with increase in age of plant

The nitrogen free extract (NFE) of the leaves revealed fluctuating values (range of $46.05 \%$ $50.53 \%$ ) as shown in Figure 2e. No significant variations were observed with the maturity of the plant. The Nitrogen free extract of Sesamum radiatum leaves revealed that it has higher values compared to those obtained in Cochorus olitorus (26.6\%), Amaranthus cruentus (7.0\%), but is similar to that of Vernonia amygdalina (47.9\%) as reported by Mensah et al. (2008). The result showed that Sesamum radiatum leaves could not be used in soups for its carbohydrate content when compared to traditional carbohydrate sources such as rice, maize, cassava, yam, plantain etc.

\section{References}

Adepoju, O.T., Onasanya, L.O., and Udoh, C.H , (2006). Comparative studies of nutrient composition of cocoyam (Colocassia esculenta) leaf with some green leafy vegetables. African Journal of Biotechnology, 4; 497 - 501. 
Akindahunsi, A A., \& Salawu S. O. (2005). Phytochemical screening of nutrient and antinutrient composition of selected tropical green leafy vegetables. African Journal of Biotechnology, 4, 497-501.

Akubugwo, I E., Obasi N.A., Chinyere G.C., \& Ugbogu A.E. (2007). Nutritional and Chemical value of Amaranthus hybridus L. Leaves from Afikpo. Nigerian African Journal of Biotechnology, 6, 2833-2839.

AOAC. (2000). Official Methods of Analysis Washington D.C. (17 ${ }^{\text {th }}$ Ed.): Association of Official Analytical Chemists.

Auwalu, B.M., \& Babatunde F.E. (2007) Analyses of Growth, Yield and fertilization of vegetable sesame (Sesame radiation schum). Journal of Plant Sciences, 2(1), 108-112. http://dx.doi.org/10.3923/jps.2007.108.112

Chinma, C.E., \& Igyor, M.A. (2007). Micronutrient and antinutritional contents of selected tropical vegetables grown in South East, Nigeria. Nigerian Food Journal, 25, 111-116.

Dairo, F.A.S., \& Adanlawo, I.G. (2007). Nutritional Quality of Crassocephalum crepidiodes and Senecio biafrae. Pakistan Journal of Nutrition, 6(1), 35-39. http://dx.doi.org/10.3923/pjn.2007.35.39

Emebu, P. K., \& Anyika J. U. (2011). Proximate and Mineral Composition of Kale (Brassica oleracea ) Grown in Delta State, Nigeria. Pakistan Journal of Nutrition, 10(2), 190-194. http://dx.doi.org/10.3923/pjn.2011.190.194

Guarino, L. (1995). Traditional African vegetables: Proceedings of the ICGRI International Workshop on Genetic Resources of Traditional Vegetables in Africa. 29-31 August, ICRAF Headquarters Nairobi, Kenya.pp4.

Hall, R. (1998). Kale, Brassica oleraceae (Acephala group). USDA Database for standard reference, release 12. About.com.Nutrition guide.http://www.nutrition.about.com. Accessed 03/02/2011.

Mensah, J.K., Okoli, R.I., Ohaju-obodo, J.O., \& Eifediyi K. (2008). Phytochemical, nutritional and medical properties of some leafy vegetables consumed by Edo people of Nigeria. Africa. Journal of Biotechnol, 7, 2304-2308.

Mosha, T. C., Gaga, H. E., Pace R.D., Laswai, H. S., \& Mtebe, K. (1995). Effect of blanching on the content of antinutritional factors in selected vegetables. Plant Foods for Human Nutrition, 47, 361-367. http://dx.doi.org/10.1007/BF01088275

Omidiji M. O. (1978). Tropical leafy and fruit vegetables in Nigeria. Vegetable for Horticultural Humid Tropics, 3, 6-8.

Oyenuga V.A., \& Fetuga B.L. (1975). Dietary importance of fruits and vegetable. Proceedings of the $1^{\text {st }}$ National seminar on fruits and vegetables. University of Ibadan, Nigeria: pp 122-131. 